\title{
Lumen
}

Selected Proceedings from the Canadian Society for Eighteenth-Century Studies

\section{The Rediscovery of Frances Burney's Plays}

\section{Peter Sabor}

Volume 13, 1994

URI : https://id.erudit.org/iderudit/1012530ar

DOI : https://doi.org/10.7202/1012530ar

Aller au sommaire du numéro

Éditeur(s)

Canadian Society for Eighteenth-Century Studies / Société canadienne d'étude du dix-huitième siècle

ISSN

1209-3696 (imprimé)

1927-8284 (numérique)

Découvrir la revue

Citer cet article

Sabor, P. (1994). The Rediscovery of Frances Burney's Plays. Lumen, 13,

145-156. https://doi.org/10.7202/1012530ar d'utilisation que vous pouvez consulter en ligne.

https://apropos.erudit.org/fr/usagers/politique-dutilisation/ 


\section{The Rediscovery of Frances Burney's Plays}

In October 1799, Charles Burney Jr. wrote to his sister Frances, telling her that Thomas Harris, manager of the Covent Garden Theatre, admired her comedy Love and Fashion and would put it on stage in March of the following year. Charles continued: ' $\mathrm{H}$ [arris] is surprised, that you never turned your thoughts to this kind of writing before; as you appear to have really a genius for it! - There now! $!^{1}$ The exclamation serves in part to emphasize Charles's pleasure in hearing Love and Fashion praised by so important a theatrical figure as Harris. It also, however, points to Harris's ignorance of Burney's previous dramatic works: in particular a comedy, The Witlings, that she had written twenty years earlier, but that had never been printed or performed.

In 1799, Burney was among the best-known novelists of the day. Her brilliant early success, Evelina (1778), had been followed by the equally popular Cecilia (1782); both novels went through many editions, were rapidly translated into several languages, and were respectfully reviewed. Her third novel, Camilla (1796), met with more criticism, but it too sold several thousand copies and brought wealth as well as fame to its author, who could buy a cottage with the proceeds.

Few of Burney's contemporaries, however, knew much about her other literary career as a dramatist. She had begun writing The Witlings in 1778, soon after the publication of Evelina, and had it ready for performance in early 1780. During her five unhappy years of service at court, 1786 to 1791, she had started work on four blank-verse tragedies: Edwy and Elgiva, which she began in 1788 and was still revising in 1795; Hubert De Vere, begun in 1790 and revised until 1797; The Siege of Pevensey, also begun in 1790 and completed at an unknown date; and Elberta, begun in 1791, never completed, but revised at least as late as 1814, after the publication of her final novel The Wanderer. A third wave of playwriting started in 1798, when she began work on Love and Fashion and may have had a hand in a comedy apparently written by her brother-inlaw Ralph Broome, a one-act farce, The Triumphant Toadeater. ${ }^{2}$ Finally, between 1800 and 1802 , she wrote what are arguably her two finest plays, the comedies The Woman-Hater and A Busy Day. 
Most of the debate over Burney's plays during her lifetime was conducted not in public - among theatre-goers and theatre critics or in the pages of literary magazines - but in private: in conversations among members of her family and close friends, in correspondence, and in the pages of diaries and journals. The Witlings, in particular, generated copious commentary in 1779 from her father, Charles Burney, and her adopted father-figure, Samuel Crisp, much of it directed towards telling her why the comedy should not be performed. Although she was encouraged by two experienced dramatists, Richard Sheridan and Arthur Murphy, who read the play in progress, as well as by Samuel Johnson, Joshua Reynolds, and Hester Thrale, Charles Burney and Crisp were adamant that it should be suppressed. Their joint condemnation was conveyed in a letter no longer extant, memorably described by Burney in a letter to Crisp as 'that hissing, groaning, catcalling epistle. ${ }^{\prime 3}$ To her father she wrote, 'You have finished it now in every sense of the word, ${ }^{4}$ and although she subsequently dwelt on the possibility of revising the play, The Witlings was to remain unperformed and unpublished for over two hundred years. Dr. Burney, who felt that its satire of the bluestockings in general and of Elizabeth Montagu in particular would damage his daughter's reputation, declared that 'not only the Whole Piece, but the plot had best be kept secret, from every body. ${ }^{, 5} \mathrm{~A}$ further reason for suppression given by Samuel Crisp was the play's resemblance to Molière's Les Femmes Savantes, to which Burney later responded by denying that she had so much as read Molière's comedy. ${ }^{6}$ What is vexing for the modern reader in all this, is that the protracted debate over The Witlings took the place of a dramatic performance, by which the play's merits could have been put to the test. In a later letter, Crisp declared that 'the story and the incidents don't appear to me interesting enough to seize and keep hold of the attention.... This, to me, is its capital defect ${ }^{\prime 7}$ - and this at a time when Sheridan was still asking for the opportunity to produce the play at Drury Lane.

Remarkably, the whole cycle of composition, would-be production, and suppression was repeated twenty years later when Burney wrote her second comedy, Love and Fashion. Thomas Harris offered Burney the considerable sum of $£ 400$ for the play - a sign of the seriousness of his intentions about producing it - and spread word of the impending performances through newspaper announcements. The Morning Chronicle of 29 January 1800 noted that 'Madame d'Arblay, ci-devant Miss Burney, has a Comedy forthcoming at Covent-Garden Theatre,' an unfortunate notice which at once attracted Charles Burney's attention with its references to Burney's maiden and married names. ${ }^{8}$ Shortly after the announcement appeared, Burney wrote to her father, telling him that Harris had agreed to withdraw Love and Fashion from production and 
would attempt 'to keep the news papers totally silent in future. ${ }^{9}$ The mature author of Love and Fashion, however, unlike the inexperienced would-be dramatist who wrote The Witlings, had no intention of suppressing the play indefinitely. The death of her sister Susanna in January 1800 accounted for her agreeing to a temporary withdrawal of the comedy, but Burney still intended to see the play on stage. Her letter to her father makes it clear that he had not read the manuscript: 'appear when it will, you will find nothing in the principles, the moral, or the language that will make you blush for me.' Her hopes for a future production, however, were not to be fulfilled. And neither of the two other comedies that she wrote in the first years of the new century - The Woman-Hater and A Busy Day - seems ever to have been shown to a theatre manager or even read by members of her family, although Burney's tentative cast-lists show that The Woman-Hater was intended for production at Drury Lane, and A Busy Day at Covent Garden.

When Burney's contemporaries thought of her as a dramatist at all, it was as the author of a tragedy, Edwy and Elgiva. The play was produced for only one night at the Drury Lane Theatre on 21 March 1795, but reviews of this performance appeared in at least five Sunday and eighteen daily London newspapers, as well as in two monthly magazines. ${ }^{10}$ Most of these reviews blamed the play's failure at least partly on the remarkably poor acting, although Sarah Siddons and John Philip Kemble in the principal roles and Robert Bensley as Dunstan were spared from the general censure. Burney herself, who attended the performance, claimed in a letter that John Palmer, who played the part of Bishop Aldhelm, had 'but 2 lines of his part by Heart! he made all the rest at random $-\&$ such nonsence as put all the other actors out as much as himself. ${ }^{11}$ Reviewers agreed; the Whitehall Evening Post and Morning Herald review, for example, declared that 'making Palmer a Bishop was an idea rather whimsical; he was extremely imperfect.' The Morning Chronicle noted that most of the actors 'either knew not a line of their parts, without the aid of the Prompter, or seemed inclined to turn the whole into ridicule.' The Morning Advertiser was still more blunt: 'The Acting was disgraceful to the Company, and shamefully injurious to the Author... the Prompter was heard unremittingly all over the House. If the Piece was accepted, it should have been played.'

Combined with such criticisms of the cast were complaints about Burney's lack of theatrical experience. The reviewer for the Oracle, who had appreciated the 'dramatic power' of Burney's character-drawing in Cecilia, believed that 'of the Stage, this elegant writer knows nothing, and... she appears to have had no friend who knew more.' The Morning Post likewise complained that the play was 'one continued monotonous scene of whining between the two lovers, occasionally interrupted by the 
insolent Dunstan,' that 'the Author seems to have no idea of stage effect,' and that 'the entrances and exits are ill managed.' In addition, neither the prologue, written by Charles Burney, nor the epilogue, by Burney herself, met with approval. The Times described the prologue as 'a tedious descant on the Three Ages of Religion,' which 'seemed almost an age in the delivery,' while the True Briton claimed that it took 'nearly as long as the ordinary Act of a Play.'

Another frequent object of criticism were various unwitting descents into bathos. 'Bring in the Bishop' was a particularly unfortunate line, the consequences of which were later described by Siddons's biographer Thomas Campbell, drawing on the newspaper accounts: 'At that time there was a liquor much in popular use, called Bishop... when jolly fellows met at a tavern, the first order to the waiter was, to bring in the Bishop.' Burney was 'unacquainted with the language of taverns,' and 'the summons filled the audience with as much hilarity as if they had drank of the exhilarating liquor. ${ }^{12}$ An exclamation by Dunstan - 'Will not the roof drop in?' - was also said in the Observer to have 'excited the risible faculties of the audience.'

Despite these and many other caustic observations, however, the theatre reviews were not entirely negative. Two papers, the Review and the Gazeteer, commended Burney's adaptation of her source, Hume's History of England, in depicting Edwy's disastrous love for Elgiva. There was praise in the Telegraph for the confrontation scenes in Acts II and III between Edwy and Dunstan, 'marked with an energy and eloquence much superior to any modern effort,' and for Burney's 'forcible and new' sentiments, contrasted with the 'nauseous bombast' of other recent tragedies. ${ }^{13}$ The Gazeteer believed that once the tragedy had been shortened 'and the action of the play thus quickened' it was sure to succeed: 'it can require only to be seen to be successful'. Similarly positive was a review in the European Magazine, declaring that 'the construction of the Play was entitled to applause, and the language was beautiful and poetical.' The reviewer suggests that Edwy and Elgiva might still 'afford much pleasure in the closet, and with a few curtailments and alterations might have claimed its place on the Theatre. ${ }^{14}$

Revising Edwy and Elgiva as a closet drama, rather than hazarding the trials of another stage production, was an option that Burney considered. The London Packet concluded its review with the suggestion that the play 'will probably read much better than ever it can be made to act,' and Burney received at least three letters urging her to publish Edwy and Elgiva by subscription. ${ }^{15}$ Her failure to do so, or to see any of her other plays into production or print, accounts for her long oblivion as a dramatist. Thomas Campbell, who devoted a page of his Life of Mrs. Siddons (1834), published near the end of Burney's long life, to the 
production of Edwy and Elgiva, was clearly writing with no personal knowledge of the play, for readers unaware that the celebrated novelist had ever written a tragedy.

After Burney's death in 1840, her already little-known plays fell into still deeper obscurity. Those few critics who discussed them at all did so without what might seem to be the necessary prerequisite of having read them. Macaulay, for example, in his long and highly influential essay on Burney of 1842, asserts that 'The Witlings would have been damned, and that Murphy and Sheridan thought so, though they were too polite to say so.' He goes on to congratulate Crisp for 'manfully' counselling Burney against production of the play, thus acting as 'a judicious, faithful, and affectionate adviser.' Surprisingly, after this bravura piece of pseudo-criticism, Macaulay is more reticent about Edwy and Elgiva, admitting that 'we do not know whether it was ever printed; nor indeed have we had time to make any researches into its history or merits. ${ }^{16}$ Austin Dobson, writing on Burney in 1903 in the 'English Men of Letters' series, devotes four pages to The Witlings, again without the benefit of having read it, and concludes, like Macaulay, that Dr. Burney and Crisp were right to have suppressed the play. Turning to Edwy and Elgiva, Dobson declares that 'though at some points there is a certain stir and action, the plot generally lacks incident and movement ${ }^{\prime 17}$ - although no copy of the play was available to him.

There are, I believe, only two nineteenth- or early twentieth-century critics with first-hand knowledge of a Burney play. One, Evelyn Shuckburgh, who possessed a manuscript of Edwy and Elgiva, discusses the tragedy in some detail in an article of 1890 . He pronounces it 'ludicrously bad,' vitiated by 'absence of movement and action,' 'the incurable poverty of its stilted language, its commonplace sentiments, and its incorrect and inharmonious versification,' and he supports his case with textual quotations. ${ }^{18}$ Shuckburgh was not, however, aware that the pencilled 'alterations and improvements' in his manuscript were not by Burney but by her husband, Alexandre d'Arblay; nor did he know of Burney's having written any other plays. ${ }^{19}$ Although his article provided Dobson with material for his book, it made little subsequent impression. Joseph Grau, Burney's bibliographer, mistitles it and lists it as 'not seen. ${ }^{, 20}$

Another exception to the rule of writing on Burney's plays without reading them is made in Constance Hill's The House in St. Martin's Street (1907). Hill transcribes part of Act IV of The Witlings from Burney's manuscript, the first printing of at least part of any Burney play, and remarks that 'we have read the play with much interest and amusement, though recognizing some of the drawbacks which struck Dr. Burney and Mr. Crisp so forcibly'. This and a reference to the comedy's 'bright dialogue,' faint praise though it is, is still exceptional; for once a critic 
had found a Burney play worthy of extensive quotation, and of at least qualified approval. ${ }^{21}$ An anonymous reviewer of Hill's book in the Times Literary Supplement, however, thought otherwise, stating that 'we had always cherished a secret hope that... Dr. Burney and Daddy Crisp were over severe when they counseled her against publication, but, from the specimen here given, it's clear that they were right. ${ }^{22}$

The modern rediscovery of Burney's plays was made possible by the acquisition in 1941 of a huge number of her manuscripts, hitherto in a private collection, by the Berg Collection of the New York Public Library. This archive, which includes manuscripts of all of her plays, was made available to scholars in $1945 .^{23}$ The first critic to take advantage of the newly available material was Joyce Hemlow, who in 1950 published an article with what then must have been a startling title, 'Fanny Burney: Playwright.' Until this piece appeared, even the existence of two of Burney's comedies, A Busy Day and The Woman-Hater, and three of her tragedies - Hubert De Vere, The Siege of Pevensey, and Elberta - was unknown. Hemlow offered, for the first time, an overview of the plays. She found The Witlings disappointing, with 'fewer comic transcripts of life than readers of Evelina might have expected,' but was more impressed by the later comedies, especially A Busy Day, 'with its original scenes and its realistic and satiric comedy.' The tragedies Hemlow regarded as complete failures, typifying the weaknesses of 'she-tragedy,' with its 'falling into mawkishness. ${ }^{24}$ Hemlow expanded this criticism in her biography of Burney of 1958, in which she further argued that these 'experiments in blank verse, scarcely to be considered as poetry, had a deplorable effect on her prose style.' They gave rise, she claims, to 'a flamboyant rhetoric' and an 'empty swollen manner' that created a 'peculiarly hollow, half-romantic, half-sentimental effect' in Burney's later prose. ${ }^{25}$

A year before Hemlow's biography appeared, one of these tragedies, Edwy and Elgiva, was published for the first time. Its editor, Miriam J. Benkovitz, however, held it in no higher regard than did Burney's biographer. Her introduction constitutes a sustained attack on the play, with its 'artificial pathos' in which 'feeling degenerates into mere rhetoric... the failure of Edwy and Elgiva is a failure in style.' Like Hemlow too, Benkovitz associates the convoluted language of Edwy and Elgiva with an ensuing deterioration in Burney's works, contending that the play 'marks the very point of decline' in her career. ${ }^{26}$ If this edition had been more widely read, it might have affected Burney's already low reputation as a dramatist adversely. It was, however, ignored by reviewers, has long been out of print, and has seldom been cited by Burney's recent critics. 
Among the few critics other than Hemlow to take an overview of Burney's plays is Michael Adelstein in his Twayne volume of 1968. Adelstein prizes The Witlings more highly than any previous commentator, contending that its suppression was 'detrimental to [Burney's] artistic development.' He regards Burney as a natural satirist, forced to abandon satire after The Witlings had been condemned. He is less impressed by two of Burney's later comedies, Love and Fashion and The Woman-Hater, but in a panegyric on A Busy Day, Burney's 'Unpublished Masterpiece,' he pronounces it 'worthy of being read and acted today along with such eighteenth-century favorites as Sheridan's School for Scandal and Goldsmith's She Stoops to Conquer.' It has, he believes, 'an appealing freshness and sparkle found in few other eighteenth-century comedies.' If Burney had continued to write comic dramas instead of producing her final novel, The Wanderer, she would, Adelstein contends, be more highly regarded today. ${ }^{27}$

A similar argument about the relative merits of Burney's dramas and novels is made in Ellen Moers's early feminist study, Literary Women (1976). Oddly, despite her admiration for The Witlings as 'very funny and quite stageworthy,' Moers is relieved that the play was suppressed: 'Had Dr. Burney allowed The Witlings to go on the boards, his daughter would have been convicted of a tasteless gaffe equivalent to, say, the submission by an aspiring young authoress of a nasty satire on Gloria Steinem to Ms. magazine.' Moers believes, however, that playwriting was Burney's true vocation, and despite not having read the three late comedies she speculates about 'what might have happened to the English theatre had Jane Austen followed in Fanny Burney's footsteps as a playwright rather than as a novelist. ${ }^{28}$ Here we return to the kind of impressionism that characterizes Macaulay's essay on Burney: a critic uses unread comedies by Burney to envisage unwritten plays by Austen.

Burney's final comedy, A Busy Day, received further prominence when it was edited by Tara Ghoshal Wallace in a critical edition, first as a University of Toronto doctoral dissertation and then as a book in 1984. An enthusiastic advocate for Burney as comic dramatist, Wallace admires The Woman-Hater as much as A Busy Day, and believes that both had 'every chance of success on stage. ${ }^{29}$ Reviewers, however, were unimpressed. Pat Rogers, whose Times Literary Supplement notice is entitled 'On the mild side,' terms A Busy Day 'a mild comedy of manners, its action comfortably mid-Augustan in feel,' although the language is 'recognizably more modern than anything in Fanny's novels. ${ }^{30}$ Lillian Bloom, in her review, contends that A Busy Day does not justify its editor's labours; as a comedy of manners it is a 'tattered copy' of Sheridan and Goldsmith, marred by 'dullness and confusion. ${ }^{31}$ 
Had A Busy Day been published in the late, rather than in the mid 1980s, it might have met with a better reception. Since 1987, Burney's critical standing has risen dramatically. At least ten full-length studies of her life and writings have been published between 1987 and 1994, together with two new editions each of Evelina, Cecilia and The Wanderer, and the first three volumes of an edition of her early journals and letters. Three of the critical studies make strong claims for Burney's plays. Judy Simons, in her slim monograph of 1987, terms Burney 'an extremely talented playwright,' and believes that A Busy Day, in particular, 'completely fulfils the promise of Evelina, albeit some twenty years late. ${ }^{32}$ Katharine Rogers, in her Frances Burney (1990), echoes Ellen Moers, terming The Witlings 'a hilariously funny play,' but finding 'Burney's choice of subject... singularly perverse, since the main object of satire is intellectual women. ${ }^{33}$

Neither Simons nor Rogers has anything positive to say about Burney's tragedies, which Simons terms 'dismal exercises in heroic drama' that 'deal yet again with female victimisation.' Margaret Anne Doody, in contrast, in her Frances Burney: The Life in the Works (1988), is an advocate for Burney as both comic and tragic dramatist. In an essay of 1985, Doody had contended that Burney might 'win posthumous reputation as a dramatist as her previously unpublished comic plays emerge into print. ${ }^{34}$ Her critical biography reinforces this claim with a detailed analysis of each of the plays. In The Witlings, she sees Burney as 'a predecessor of Pinero or Ayckbourn.' Writing on the tragedies, Doody, like Benkovitz and Hemlow, finds a link between their style and subject matter and those of the later novels. Unlike these earlier critics, however, Doody regards the effect of the tragedies as beneficial to Burney the novelist: the 'vision of the depths' in Camilla and The Wanderer grows out of the intense introspection of the tragic dramas. Doody also studies The Woman-Hater as a play closely related to Burney's novels; she terms it a 'nodal work,' attempting to resolve issues dealt with in Burney's fiction, tragic dramas and comedies alike. ${ }^{35}$

Doody's seminal work on Burney has paved the way for the critical rediscovery of Burney's plays, which can no longer be dismissed as a negligible part of her literary œuvre. Since the publication of Doody's biography in 1988, The Witlings has been edited as a doctoral dissertation and appeared in a collection of plays by eighteenth-century women dramatists. ${ }^{36}$ Another doctoral dissertation has furnished the first fulllength critical study of Burney's plays. ${ }^{37}$ And my own collected edition of the plays makes all of Burney's comedies and tragedies readily available for the first time. ${ }^{38}$ This edition will enable critics to give Burney's plays the sustained attention that her novels have lately received and to consider Burney's writings as a whole, recognizing that each of her first 
three novels was followed by a play or group of plays. With the recent resurgence of interest in Gothic drama, a new context exists in which to study Burney's much disparaged tragedies. In addition, criticism of Burney's tragedies and comedies alike can profit from recent studies of eighteenth-century women dramatists; the period (1778-1802) in which Burney wrote her plays was also that in which writers such as Hannah Cowley, Hannah More, Elizabeth Inchbald, Sophia Lee, and Joanna Baillie were active.

Another striking sign of the renewed interest in Burney as playwright is the success of a recent production of A Busy Day, its world premiere and only the second production of any Burney play. Directed by Alan Coveney, the play was performed by the Show of Strength company at the Hen and Chicken Theatre, Bedminster, England, for four weeks from 29 September to 23 October 1993. In a programme note, Coveney describes his discovery in early 1992 of Wallace's edition of A Busy Day, remaindered in a bookshop, and his enthusiasm for 'this wonderful play,' which had 'lain dormant, waiting for a theatre to discover it and for actors to bring its marvellous characters to life.' The company won a $£ 16,000$ award from London Weekend Television, enabling it to construct elaborate sets, including one of Kensington Gardens, for the production, which played to a full house throughout its run. Another performance, without the sets but in period costume, took place by Burney's cenotaph at Walcot Parish Church in Bath. ${ }^{39}$

Reviews of the Show of Strength production were far more positive than those of Edwy and Elberta nearly two hundred years earlier. Malcolm Rutherford in the Financial Times, for example, described it as 'a fizzing production of a very funny play,' while Jeremy Brien in The Stage wrote that 'on the evidence of A Busy Day, Fanny Burney's true metier was the stage. This is a portrait of English society of the late 18th Century at least as scathing as anything from Goldsmith - and considerably funnier.' A.C. Smith in the Guardian preferred the second half of the performance with its 'essence of malice' to the slower and wordier opening acts and found the plot 'as corny and confusing as most plays of the period.' Wayne Stackhouse in the Bristol Observer, however, compared A Busy Day favourably with Jane Austen's novels: it 'packs more of a satirical bite and has a bawdy feel that Jane Austen lacks; this is a bit like Austen meets Ayckbourn.... The irony, in these post-Thatcher days, of a clash between a pretentious but penniless aristocracy and an unrefined nouveau-riche is also nicely observed.' And Helen Reid, in the Western Daily Press, declared that the play 'must not be allowed to fade into obscurity again, for with judicious editing it could become a national classic - few 18 th century plays are as funny as this one. ${ }^{40}$ 
In March 1795, a journalist in The True Briton, writing before the premiere of Edwy and Elgiva, declared that 'Green-room report is not on the whole unfavourable, though it is said that some passages border too much upon the familiar. ${ }^{41}$ Much subsequent commentary on Burney's plays has been mere gossip of this kind. With the full extent of her writings for the theatre now established, with these writings available in print, and with the advent of new stage productions, critics should no longer need to discuss Burney's merits or failings as a dramatist without having read or seen performances of her plays.

\section{PETER SABOR \\ Queen's University}

\section{Notes}

1 The Journals and Letters of Fanny Burney (Madame d'Arblay), 1791-1840, ed. Joyce Hemlow et al. (Oxford: Clarendon Press, 1972-84), IV, 361.

2 Betty Rizzo has recently identified the hand in which The Triumphant Toadeater is transcribed as that of Ralph Broome, second husband of Burney's sister Charlotte (Companions Without Vows: Relationships Among Eighteenth-Century British Women [Athens: University of Georgia Press, 1994]), p. 349, n. 38.

3 Letter of c. 13 August 1779; The Early Journals and Letters of Fanny Burney, ed. Lars E. Troide et al. (Oxford: Clarendon Press, 1988- ), III, 350.

4 Letter of c. 13 August 1779; Early Journals and Letters, III, 345.

5 Letter to Frances Burney of 29 August 1779; The Letters of Dr Charles Burney, ed. Alvaro Ribeiro (Oxford: Clarendon Press, 1991), I, 280.

6 Burney's note on her letter to Charles Burney, c. 13 August 1779; Early Journals and Letters, III, 345.

7 Letter to Burney of 23 February 1780; Early Journals and Letters, IV, forthcoming.

8 Journals and Letters, IV, 392-93, n. 4.

9 Letter of 10 February 1800; Journals and Letters, IV, 394.

10 Twenty-two of these newspaper reviews, all from 22 and 23 March 1795, survive in the Burney Collection, British Library, and have been microfilmed. Another, in the London Chronicle, is missing from the Burney Collection but is quoted by Thomas Campbell in The Life of Mrs. Siddons (1834; rpt. New York: Blom, 1972), p. 266. Several of the newspapers print the same review in whole or in part. Excerpts from some of the reviews are printed in Journals and Letters, III, 366-67. In addition to the eleven daily newspapers with reviews listed there, the following, all in the Burney Collection, also contain reviews: St. James's Chronicle, Whitehall Evening Post, London Packet or New Lloyd's Evening Post, The Courier and Evening Gazette, The Sun, and The Star. The last two are wrongly said in Journals and Letters to be missing from the Burney Collection. 
11 Letter to Georgiana Waddington of 15 April 1795; Journals and Letters, III, 100. Palmer, although a prominent actor, had a reputation for forgetting the words to some of his parts; for several examples, see Charles Beecher Hogan, ed., The London Stage, Part 5: 1776-1800 (Carbondale: Southern Illinois University Press, 1968), pp. cxvi-cxviii. For another instance, see Isobel Grundy, 'Sarah Gardner: "Such Trumpery" or "A Lustre to Her Sex"?,' Tulsa Studies in Women's Literature, 7, no. 1 (1988), 11.

12 Life of Mrs. Siddons, p. 267.

13 In printing an excerpt from this review, the editors of Letters and Journals wrongly suggest that the phrase 'nauseous bombast' was applied to Edwy and Elgiva itself (III, 366).

14 European Magazine, 27 (April 1795), 272. This review was reprinted in Walker's Hibernian Magazine, Part 1 (May 1795), 437.

15 See Journals and Letters, III, 110; and my article "'Altered, improved, copied, abridged": Alexandre d'Arblay's Revisions to Burney's Edwy and Elgiva', Lumen, 14 (1995), forthcoming.

16 Thomas Babington Macaulay, 'Madame D'Arblay', Edinburgh Review, 76 (1843), $539,558$.

17 Dobson, Fanny Burney (Madame d'Arblay) (London: Macmillan, 1904), 100-5, 185.

18 Shuckburgh, 'Madame d'Arblay', Macmillan's Magazine, February 1890, p. 294. Shuckburgh presented the manuscript to Emmanuel College, Cambridge, its present location.

19 For a study of these revisions, see my "'Altered, improved, copied, abridged": Alexandre d'Arblay's Revisions to Burney's Edwy and Elgiva'.

20 Grau, Fanny Burney: An Annotated Bibliography (New York: Garland, 1981), p. 147.

21 Hill, The House in St Martin's Street (London: Bodley Head, 1907), p. 153.

22 Times Literary Supplement, 9 November 1906, p. 376; quoted in Grau, p. 188.

23 See Joyce Hemlow, A Catalogue of the Burney Family Correspondence 1749-1878 (New York: New York Public Library, 1971), p. xiv.

24 Hemlow, 'Fanny Burney: Playwright', University of Toronto Quarterly, 19 (1949-50), 171, 189, 176.

25 Hemlow, The History of Fanny Burney (Oxford: Clarendon Press, 1958), pp. 220-21.

26 Benkovitz, ed., Edwy and Elgiva (Hamden, Conn.: Shoestring Press, 1957), pp. xiii-xiv.

27 Adelstein, Fanny Burney (New York: Twayne, 1968), pp. 61, 112, 116.

28 Moers, Literary Women (New York: Oxford University Press, 1985), pp. 117-18.

29 Wallace, ed., A Busy Day (New Brunswick, New Jersey: Rutgers University Press, 1984), p. 160.

30 Rogers, Times Literary Supplement, 7 June 1985, p. 642.

31 Bloom, The Eighteenth Century: A Current Bibliography, n.s. 10 (New York: AMS, 1989), p. 576.

32 Simons, Fanny Burney (Totowa, New Jersey: Barnes and Noble, 1987), p. 133. 
33 Rogers, Frances Burney: The World of Female Difficulties (London: Harvester Wheatsheaf, 1990), p. 19.

34 Doody, 'Fanny Burney,' in Dictionary of Literary Biography, 39, British Novelists, 1660-1800, ed. Martin C. Battestin (Detroit: Gale, 1985), p. 91.

35 Doody, Frances Burney: The Life in the Works (Cambridge: Cambridge University Press, 1988), pp. 98, 198, 302. Doody also draws attention to The Triumphant Toadeater, contending that the 'evidence is all against' Burney's authorship and attributing the farce tentatively to Burney's sister Charlotte (pp. 292, 419).

36 The Witlings, ed. Clayton Delery, Ph.D. diss. (City University of New York, 1989); The Meridian Anthology of Restoration and Eighteenth-century Plays by Women, ed. Katharine M. Rogers (New York: Meridian, 1994).

37 Barbara Darby, 'Family and Feminism in the Plays of Frances Burney', Ph.D. diss., Queen's University, 1994. Two earlier doctoral dissertations studied Burney's plays in relation to her fiction: Marjorie Lee Morrison, 'Fanny Burney and the Theatre', University of Texas, 1957; Elizabeth Yost Mulliken, 'The Influence of the Drama on Fanny Burney's Novels', University of Wisconsin, 1969.

38 The Complete Plays of Frances Burney, ed. Peter Sabor, contributing editors Stewart Cooke and Geoffrey Sill (London: Pickering \& Chatto, 1995).

39 For information about the production, including press clippings, I am indebted to Sheila Hannon, Administrator of the Show of Strength company.

40 Financial Times, 2-3 October 1993; The Stage and Television Today, 11 November 1993; The Guardian, 6 October 1993; Bristol Observer, 8 October 1993; Western Daily Press, 30 September 1993. Other reviews include those by Christopher Hansford in the Evening Chronicle (Bristol), 30 September 1993; the University of Bristol Newsletter, 14 October 1993; Chris Allen in Plays and Players, November 1993; Jonquil Panting in Venue, 15-29 October 1993; and Andrew Porton in Epigram, 7 October 1993.

41 See The Piozzi Letters, vol. 2, 1792-1798, ed. Edward A. Bloom and Lillian D. Bloom (Newark: University of Delaware Press, 1991), p. 138, n. 16. 